\title{
TELAAH PENULISAN KARYA SASTRA SEJARAH SEBAGAI REFLEKSI SUMBER PEMBELAJARAN SEJARAH
}

\author{
Moch. Nurfahrul Lukmanul Khakim \\ SMK An-Nur Bululawang Malang
}

\begin{abstract}
Abstrak. Sejarah pada umumnya ditulis dalam bentuk buku ilmiah yang sulit dipahami. Seiring dengan perkembangan teknologi, sejarah juga diungkap dalam bentuk buku menjadi bentuk bacaan lain seperti karya sastra sejarah, baik berupa puisi, cerpen, dan novel. Sudah bukan hal baru saat sejarah menjadi sumber ide karya sastra. Sebenarnya ada hal yang menarik dalam mengamati maraknya karya sastra berlatar sejarah. Karena karya sastra berlatar sejarah harus menggunakan riset yang mendalam untuk memperkuat suasana sejarah dalam ceritanya. Hal ini juga penting untuk memperkuat fakta sejarah sehingga latar sejarah yang digunakan dalam karya sastra tersebut valid dan tidak berdasarkan imajinasi penulis saja. Bagaimana pun juga, ini adalah karya sastra berlatar sejarah jadi perlu disusun berdasarkan kaidah penulisan sejarah.

Kata-kata kunci: Karya Sastra Sejarah, Novel, Puisi, Cerpen

Abstract. History is generally written in the form of scientific book which is difficult. In the development of technology, history is formed in the other form of historical works. Those works are literary works comprising poetry, short story, and novel. History should be interpreted as a narrative work. However, the literary works using historical background need a depth research to enforce the sense of history in its story. This is important to enforce the historical fact therefore the used historical background in its literary work is reliable and is not based on the author's imagination. The literary work based on historical background needs to be arranged by following the guidance of historical writing.
\end{abstract}

Keywords: historical literary work, novel, poetry, short story

Sejarah pernah menjadi bagian dari sastra. Sampai saat ini sejarah juga dekat dengan sastra, terutama dalam hal penggunaan sumber naskah tertulis. Sejarah kini sudah masuk dikenal masyarakat ke dalam berbagai bentuk. Sejarah pada umumnya ditulis dalam bentuk buku ilmiah yang sulit dipahami. Seiring dengan perkembangan teknologi, sejarah juga diungkap dalam bentuk buku menjadi bentuk bacaan lain seperti karya sastra sejarah, baik berupa puisi, cerpen, dan novel.

Hal yang menarik dari penerbitan dan peredaran karya sastra berbau sejarah adalah karya sastra ini justru lebih banyak diminati dibandingkan buku sejarah pada umumnya. Masyarakat berbondong-bondong membeli karya sastra sejarah berupa novel dan kumpulan cerpen di toko buku. Novel berlatar sejarah terjual yang laris dan memiliki animo tinggi dari masyarakat bahkan diangkat ke layar lebar seperti novel Tenggelamnya Kapal van Der Wijck. Novel sejarah saat ini memiliki jenis yang beragam dan dapat mudah ditemukan di toko-toko buku besar di Indonesia seperti Gramedia dan Togamas.

Sebenarnya ada hal yang menarik dalam mengamati maraknya karya sastra berlatar sejarah. Apakah karya sastra tersebut menggunakan kaidah penulisan sejarah dalam penyusunannya? Karena karya sastra berlatar sejarah harus menggunakan riset yang mendalam untuk memperkuat suasana sejarah dalam ceritanya. Hal ini juga penting untuk memperkuat fakta sejarah sehingga latar sejarah yang digunakan dalam karya sastra tersebut valid dan tidak berdasarkan imajinasi penulis saja. Bagaimana pun juga, ini adalah karya sastra berlatar sejarah jadi perlu disusun berdasarkan kaidah penulisan sejarah.

Bagaimana dengan karya sastra berlatar sejarah yang tidak ditulis dengan kaidah sejarah? Maka karya sastra berlatar sejarah tersebut akan menimbulkan kerancuan dan ambiguitas. Karya sastra memang berisi sesuatu yang imajinatif dan fiktif tetapi isinya harus tetap berlandaskan pada kenyataan yang ada. Kenyataan dalam latar 
sejarah ialah fakta sejarah itu sendiri. Kajian penulisan sejarah pada penyusunan karya sastra sejarah ini berguna untuk menelaah kembali karya sastra berlatar sejarah yang marak diterbitkan saat ini. Harapannya kajian ini dapat menemukan garis merah mengenai pentingnya kaidah penulisan sejarah dalam menyusun karya sastra berlatar sejarah.

\section{KARYA SASTRA SEJARAH}

Kajian kali ini akan menelaah karya sastra berlatar sejarah berupa puisi, kumpulan cerpen, dan novel. Ketiga karya sastra tersebut akan ditelisik muatan isi dan cara penulisannya. Ketiga karya sastra tersebut antara lain: PostKolonial dan Wisata Sejarah dalam Sajak (Kumpulan Puisi), Semua untuk Hindia (Kumpulan Cerpen), dan Pulang (Novel). Ketiga karya sastra tersebut cukup menarik karena ketiga-tiganya pernah memenangkan penghargaan sastra terbesar di Indonesia yaitu Kusala Sastra Khatulistiwa.

Ketiga karya sastra tersebut dianggap berhasil mengangkat isu sejarah ke dalam bentuk narasi sastra yang menarik.

1. Post-Kolonial dan Wisata Sejarah dalam Sajak karya Zeffry Alkatiri (Kumpulan Puisi) Kumpulan puisi ini dibagi menjadi dua bagian utama yaitu bagian 1: Post Kolonial dan bagian 2: Wisata Sejarah . Semua puisi sejarah dalam buku ini ditulis denga teknik dramatis. Dramatis ialah teknik penulisan puisi yang di dalamnya diciptakan sebuah cerita yang melibatkan konflik atau emosi. Bagian 1: Post Kolonial berisi sekumpulan puisi tentang sejarah kolonial Belanda di Indonesia. Puisi-puisi menggambarkan kegelisahan dan refleksi sejarah kolonial Belanda dan Jepang di Indonesia. Lihatnya puisi yang berjudul Kapan Kau Datang Lagi, Jaap?. Puisi tersebut ditulis untuk memperingati dan merefleksi 410 tahun VOC, Pemerintah Jajahan Belanda, dan Kemerdekaan RI. Bagian 2: Wisata Sejarah berisi sekumpulan puisi yang lebih banyak dan lebih luas bahasannya daripada bagian 1. Puisi-puisi yang ditulis bertema sejarah Indonesia dan Dunia dengan berbagai rentang tahun yang variatif mulai dari sekitar 300 Masehi sampai 2011. Bahasa yang digunakan dalam puisi tersebut sangat refleksi dan lugas sehingga mudah dipahami. Antara lain puisi yang mengkritik penjajahan Belanda atas Indonesia berjudul Ambon, Banda, dan Batavia, 1619-1765: Biji lada, cengkeh, dan biji pala Telah menghangatkan tubuh orang-orang Eropa

Sementara sebagai gantinya mereka memberikan besi-besi panas kepada orang-orang di Hindia

Buku kumpulan puisi ini sangat cocok dijadikan alternatif bacaan sejarah. Karya sastra sejarah dalam puisi ini tampak menggunakan diksi dan riset yang baik sehingga menghasilkan puisi yang memiliki makna mendalam.

2. Pulang karya Leila S. Chudori (Novel) Mengisahkan tentang tiga peristiwa sejarah besar di Indonesia dan dunia yaitu Peristiwa 30 September 1965, Prancis Mei 1968, dan Indonesia Mei 1998. Novel ini termasuk novel penting dalam sastra dan sejarah Indonesia karena menggambarkan nasib tahanan politik Indonesia mulai dari orde lama sampai orde baru.

3. Semua untuk Hinida karya Iksaka Banu (Kumpulan Cerpen)

Berisi 13 cerita pendek tentang kolonialisasi Belanda di Indonesia. Sebagian besar cerita tentang pengkhianatan Belanda pada pribumi atau Pribumi pada Belanda atau begitu sebaliknya. Cerpen Semua untuk Hindia menunjukkan pembantaian Belanda di Bali yang dipadu dengan nuansa adat yang kental. Bagian seperti ini jarang diangkat dalam karya sejarah ilmiah di Indonesia.

Ketiga karya sastra di atas mengulas sejarah Indonesia sebagai tema besar yang digarap dengan riset mendalam. Ketiga karya sastra tersebut memenangkan penghargaan Kusala Sastra Khatulistiwa yaitu penghargaan tertinggi karya sastra di Indonesia yang rutin diadakan setiap tahun. Para pemerhati dan kritikus sastra yang menjadi juri dalam ajang sastra bergengsi itu seperti sangat paham dan 
mengapresiasi karya sastra berbasis sejarah yang menyemarakkan khazanah sastra Indonesia.

Telaah ini menunjukkan bahwa sejarah dekat dengan sastra. Sebagai catatan rekaman masa lalu, sejarah adalah bagian dari sastra. Inilah yang membuat pembelajaran sejarah sama halnya dengan pembelajaran bahasa Inggris, yang semuanya tersirat pada metode dalam memandang subjek masalah. Pada dasarnya, semua pembelajaran sejarah seharusnya mengandung penulisan yang jelas sebagaimana halnya sebuah mesin berpikir yang jelas, bersama dengan pengalaman membaca karya sastra. Pada 1980, manusia masih dapat mengira ini sama halnya membaca dan menulis sebagai gaya dasar dalam berpikir dan memahami yang akan meninggalkan dasar pendidikan sepanjang ketahanan peradaban (Daniels, 1981).

\section{PENULISAN SEJARAH PADA PENYUSUNAN KARYA SASTRA SEJARAH}

Imajinasi kesusastraan tentang kemerdekaan bahkan mendahului dan memberi ilham bagi gerakan-gerakan kemerdekaan yang menjadi agenda gerakan politik di kemudian hari (Latif, 2009:12-13). Sastra telah menyadarkan para intelektual bangsa sebagai bangsa yang harus bebas dari penjajahan. Saat kesadaran kemerdekaan ini muncul, para intelektual pribumi ini butuh wadah untuk mengatur agenda politik sehingga terbentuklah indische partij.

Menulis sendiri ialah hal yang dekat dengan kaum intelektual. Menulis merupakan mencipta, dan mencipta selalu mensyaratkan membaca. Semakin banyak mencipta, semakin banyak membaca; semakin kaya bacaan, semakin kaya hasil penciptaan (Latif, 2009:13). Menuliskan gagasan kemerdekaan dalam bentuk imajinasi sama dengan menuliskan mimpi untuk mermerdekakan bangsa Indonesia. Mimpi inilah yang terus memotivasi perjuangan bangsa Indonesia lepas dari penjajahan.

Menulis dan membaca karya sastra pada masa itu menandai kebangkitan sastra pada masa itu. Lintasan fase perjuangan kebangkitan nasional itu secara jelas menunjukkan pentingnya perjuangan $\mathrm{kata} / \mathrm{bahasa} / \mathrm{aksara} / \mathrm{sastra}$. Hal itu bukanlah khas Indonesia, karena sesungguhnya tak ada bangsa yang dapat maju tanpa memuliaan keberaksaraan dan kesastraan (Latif, 2009:13). Perjuangan bangsa Indonesia ini juga diiringi oleh kemajuan di bidang sastra. Rakyat Indonesia memuliakan dengan cara membaca dan mengapresiasi sastra sehingga rakyat Indonesia dapat memetik inspirasi mengenai kemerdekaan.

Membaca karya sastra sejarah seperti membaca karya sejarah naratif. Sejarah naratif ialah menulis sejarah secara deskriptif, tetapi bukan hanya membeberkan fakta. Ada tiga kompenen utama dalam sejarah naratif yaitu colligation, plot, dan struktur sejarah (Kuntowijoyo, 2008:147). Karya sastra juga mengenal colligation, plot, dan struktur sejarah. Struktur sejarah dalam sastra hampir dengan sama struktur sejarah antara lain manusia, tempat, dan waktu.

Karya sastra sejarah tidak boleh ditulis hanya bersumber pada imajinasi penulis. Karya sastra sejarah dalam bentuk cerita tidak dapat dipisahkan dari penyusunannya, meskipun penyusun harus berdasarkan fakta sejarah. Cerita itu tidak akan dapat disebut cerita sejarah jika penyusun utama dikuasai oleh pribadi sendiri saja dan mengabaikan fakta-fakta sejarah (Ali, 2005:35). Karya sastra sejarah harus ditulis dengan penelitian lebih dahulu menggunakan sumber-sumber sejarah yang relevan.

Suatu kejadian peristiwa yang bersifat kemanusiaan dapat dipilih dan ditentukan menjadi isi cerita sejarah apabila kejadian peristiwa itu menggambarkan perjuangan manusia ke arah kehidupan yang lebih sempurna; selain itu, juga jika kejadian peristiwa, riwayat hidup seseorang manusia itu merupakan bagian penting dari perjuangan suatu negara, kota, daerah, desa, atau lingkungan kehidupan kenegaraan (Ali, 2005:35). Karya sastra sejarah yang dibahas dalam penelitian ini sangat sesuai dengan kriteria karya sastra sejarah yang baik di atas. Karena karya sastra sejarah yang dibahas ini antara lain berjudul: Semua untuk Hindia, Pulang 
dan Wisata Sejarah dalam Sajak melukiskan kehidupan manusia menuju kemerdekaan.

Karya sastra sejarah berbeda dengan sejarah dan mitos. Berikut perbedaan antara sejarah dan mitos legenda. Perbedaan antara sejarah dan mitos legenda terletak dalam asas, metode, dan penulisan atau penyusunannya. Sejarah itu ilmiah, sedangkan mitos legenda itu tidak. Sejarah itu rasional, logis dan nyata sedangkan mitos legenda itu itu tak rasional, tak logis dan tak riel. Sejarah itu studi dari perubahan, sedangkan mitos legenda itu studi dari "ketetapan". Sejarah itu bahan untuk melihat ke depan, sedangkan mitos legenda itu untuk tetap menoleh ke belakang (Gazalba, 1981:47). Karya sastra sejarah itu memang tidak seluruhnya nyata tetapi rasional dan tetap bersumber pada kenyataan sejarah.

Karya sastra sejarah memang dianggap sebagai sebuah karya imajiner, tetapi tidak lantas diragukan kadar kebenaran atau validitas sejarahnya. Menurut Kuntowijoyo ada beberapa unsur yang mesti dimiliki sebuah karya sastra. Unsur pertama yang harus digunakan untuk mengukur kadar validitas sebuah karya sastra sejarah di antaranya: pertama, unsur historical authenticy (keaslian sejarah). Unsur ini merupakan kualitas dari kehidupan batin, moralitas, heroisme, kemampuan untuk berkorban, keteguhan hati, dan sebagainya, atau yang khas dari suatu zaman dalam sebuah karya sastra sejarah (Wibowo, 2013:91-92). Unsur historical authenticy tampak jelas pada karya sastra sejarah yang dikaji dalam penelitian ini karena menggambarkan pergulatan sejarah manusia Indonesia dalam meraih kemerdekaan.

Kedua, unsur historical faithfulness (kesetiaan sejarah). Unsur ini merupakan keharusan sejarah yang didasarkan pada basis ekonomi rakyat yang sesungguhnya. Misalnya kisah tragedi dalam cerpen Semua untuk Hindia. Kisah tersebut menggambarkan tragedi akibat "keharusan sejarah" dalam sistem peperangan kolonial di Bali. (Wibowo, 2013:92). Ketiga karya sastra sejarah yang dikaji dalam penelitian memiliki unsur historical faithfulness yang sangat jelas. Unsur historical faithfulness digambarkan dengan penelitian yang detail dan akurat mengenai para tokoh, bahkan budaya saat itu.

Ketiga, unsur local colour atau deskripsi yang setia tentang keadaan-keadaan fisik, tatacara, peralatan dan sebagainya yang membantu memudahkan penghayatan sejarah (Wibowo, 2013:92). Unsur local colour dalam ketiga karya sastra tersebut dalam dan jelas. Novel Pulang bahkan ditulis berdasarkan wawancara dengan para tokoh sejarah sehingga detail sejarah. Kumpulan cerpen Semua untuk Hindia didasarkan pada smber sejarah dan lukisan sejarah yang sezaman. Kumpulan puisi Wisata Sejarah dalam Sajak ditulis oleh dosen yang kerap melakukan penelitian sehingga kaya data sejarah. Pemilihan diksi yang tepat menjadi senjata utama dalam membuat karya sastra sejarah yang berkualitas sehingga tidak hanya memaparkan data yang membosankan. Karya sastra sejarah tersebut diharapkan bisa memberikan refleksi dan pandangan baru mengenai sejarah Indonesia.

\section{DAMPAK KARYA SASTRA SEJARAH}

Pada akhir tahun 1990, historisme yang baru itu bergerak lebih jauh dari kritik sastra yang mengasumsikan bahwa proporsi pada analisis kultural itu lebih luas.Hayden White menyarankan bahwa historisme baru itu sebenarnya memiliki usaha yang sangat kecil untuk memperbaiki dimensi historis, kajian sastra untuk menempatkan karya sastra pada konteks sejaranya untuk memahami puisi, novel, dan karya sastra lain itu tidak sesederhana dengan hubungan struktural tetapi juga koneksi asosiatif dengan masyarakat serta peristiwa historis yang mungkin mempengaruhi produktifitas mereka (Munslow, 1997:30-31).

Sesungguhnya sejarawan yang buruk adalah sejarawan yang menulis dengan tidak menarik karena sejarawan yang profesional wajib melukiskan peristiwa-peristiwa paling menggairahkan dari masa lalu dan mampu menghidupkan lagi suasananya (Gottschalk, 1975:8). Sejarawan ialah penyambung lidah antara masa lalu dan masa kini, bahkan sampai masa depan. Apabila sejarah tidak menarik untuk 
dibaca, maka tidak akan pernah ada yang mau belajar sejarah. Meninggalkan sejarah berarti meninggalkan jati diri.

Meninggalkan jati diri berarti menghapus semua yang terjadi di masa lalu tanpa pernah belajar dari kejayaan dan kesalahan yang ada. Masa lampau yang terputus dengan kekinian tidak dapat memberikan nilai edukatif apalagi kearifan sejarah. Padahal kearifan adalah suatu keteladanan. Kearifan sebagai sebuah sikap dan perilaku yang mendasar dapat dikuatkan melalui sejarah. Kearifan bahkan bisa dibentuk dengan mencermati, menghayati, dan mengamalkan nilai-nilai sejarah (Latief, 2012:71). Unsur kearifan ialah hal yang utama dalam sejarah dan karya sastra. Penulisan karya sastra sejarah yang valid dan menarik dapat memberikan keteladanan yang baik bagi pembacanya, terlebih lagi masyarakat.

Pengarang novel tidak terikat pada faktafakta sejarah mengenai apa, siapa, dan dimananya. Kesemuanya dapat berupa fiksi tanpa ada kaitannya dengan fakta sejarah tertentu. Begitu pula mengenai peristiwa-peristiwanya, maka tidak diperlukan bukti, berkas, atau saksi. Namun dalam menyusun cerita pengarang dituntut mengikuti imajinasi yang berdasarkan logika situasional, ada hubungan logis antara motivasi, sikap, dan tindakan. Merekonstruksi suatu plot (jalannya cerita perlu ada garis logis yang menghubung-hubungkan pelbagai perilaku aktor-aktor. Akhirnya, faktor perekayasaan pengaranglah yang mewujudkan cerita sebagai suatu kebulatan atau kogerensi, dan sekali-kali ada relevansinya dengan situasi sejarah (Kartodirdjo, 1993:92).

Rekonstruksi novel pada umumnya dengan novel dalam karya sastra sejarah berbeda. Secara umum rekonstruksi novel dan sejarah yaitu sejarawan maupun pengarang novel membuat rekonstruksi yang terwujud sebagai suatu konstruk yang koheren. Perbedaannya ialah bahwa yang pertama dituntut menunjuk kepada hal-hal yang memang pernah ada atau terjadi, sedang yang kedua dapat saja menggambarkan sesuatu yang tidak pernah ada atau terjadi, kesemuanya bersumber pada rekaannya (Kartodirdjo, 1993:93).

Semua cerita sejarah mempergunakan bahan sejarah dengan tujuan pasti. Isi sejarah adalah urat dagingnya dan tujuan adalah rangkanya, susunan dan cara menceritakannya adalah jiwanya. Kecakapan memilih bahan harus disertai ketegasan pendirian yang menentukan tujuan (Ali, 2005:44). Karya sastra sejarah memadukan cerita sejarah dengan gaya bercerita yang menarik sehingga jiwa zaman lebih terlihat dan terasa kuat. Karya sastra sejarah tetap berada dalam koridor sumber yang valid untuk memperkuat latar belakang cerita. Tujuan dan susunan cerita dapat disesuaikan dengan gaya bercerita.

Menulis cerita sejarah yang menarik dalam bentuk karya sastra akan membangkitkan minat pembaca untuk mengenal sejarah. Pembaca yang mengenal sejarah akan terus penasaran dengan sejarah sehingga pembaca tersebut belajar pengalaman dari bacaannya. Sejarawan yang paling banyak pengalamannya adalah sejarah yang terbak. Berpengalaman paling banyak tidak sama artinya dengan berpetualangan paling banyak. Ada orang yang lebih dapat mengerti sesamanya dengan jalan duduk di kursi dengan buku kumpulan sajak, daripada mereka yang selama ini bertugas sebagai prajurit di garis depan (Gottschalk, 1975:10). Bacaan sejarah yang menarik seperti karya sastra sejarah akan menyadarkan masyarakat mengenai pentingnya sejarah bagi kehidupan manusia.

Belajar dari pengalaman sejarah tersebut pendidikan sejarah harus didekati secara dialogis yang memungkinkan pelbagai perspektif tampil dalam penafsirannya. Sejarawan yang banyak menulis kisah sejarah sebaiknya tidak harus memaksakan paradigma/aliran pemikiran yang dianut sebagai satu-satunya kebenaran. Sejarawan harus menyadari bahwa selain pendekatan yang dipakai oleh dirinya juga ada pendekatan lain yang juga dapat dipertanggungjawabkan secara ilmiah (Haryono, 2014:16). Pendekatan karya sastra sejarah ialah pendekatan yang bisa digunakan oleh sejarawan 
dalam membangkitkan minat baca masyarakat terhadap sejarah.

Sumber belajar berkaitan dengan segala sesuatu yang memungkinkan siswa dapat memperoleh pengalaman belajar. Di dalamnya tercakup lingkungan fisik seperti tempat belajar; bahan dan alat yang dapat digunakan; personel seperti guru, petugas perpustakaan dan ahli media, dan siapa saja yang berpengaruh baik langsung maupun tidak langsung untuk keberhasilan dalam pengalaman belajar (Agung dan Wahyuni, 2013:41). Ketiga karya sastra tersebut memiliki kedekatan karakter sumber belajar tersebut dengan bimbingan guru atau pengajar yang berkompeten.

\section{PENUTUP}

Telisik muatan isi dan cara penulisannya pada karya sastra pemenang penghargaan sastra terbesar di Indonesia yaitu Kusala Sastra Khatulistiwa antara lain: Post-Kolonial dan Wisata Sejarah dalam Sajak (Kumpulan Puisi), Semua untuk Hindia (Kumpulan Cerpen), dan Pulang (Novel). Isu sejarah Indonesia yang diangkat ke dalam bentuk narasi sastra yang menarik diharapkan mampu memberikan refleksi dan pandangan baru mengenai sejarah Indonesia. Bacaan sejarah yang menarik seperti karya sastra sejarah akan menyadarkan masyarakat mengenai pentingnya belajar sejarah bagi kehidupan manusia.

\section{DAFTAR RUJUKAN}

Agung, L \& Wahyuni, S. 2013. Perencanaan dan Pembelajaran Sejarah. Yogyakarta: Ombak

Ali, R.M. 2005. Pengantar Ilmu Sejarah Indonesia. Yogyakarta: LkiS

Alkatiri, Z. 2012. Post Kolonial \& Wisata Sejarah. Jakarta: Padasan

Banu, I. 2014. Semua untuk Hindia. Jakarta: KPG Chudori, L.S. 2013. Pulang. Jakarta: KPG

Daniels, R. 1981. Studying History, How and Why. London: Prentice Hall, Inc.
Haryono. 2014. Makalah Seminar Nasional dan Lokakarya: Kekuasaan dalam Proses Pembelajaran Sejarah. Malang: FIS UM

Gazalba, S. 1981. Pengantar Sejarah sebagai Ilmu. Jakarta: Bhratara Karya Aksara

Gottschalk, L. 1975. Mengerti Sejarah. Jakarta: Penerbit UI

Kartodirdjo, S. 1993. Pendekatan Ilmu Sosial dalam Metodologi Sejarah. Jakarta: Gramedia Pustaka Utama

Kuntowijoyo. 2008. Penjelasan Sejarah. Jakarta: Tiara Wacana

Latif, Y. 2009. Menyemai Karakter Bangsa: Budaya Kebangkitan Berbasis Sastra. Jakarta: Kompas

Latief, J.A. 2012. Manusia, Filsafat, dan Sejarah. Jakarta: Bumi Aksara

Wibowo, A. 2013. Pendidikan Karakter Berbasis Sastra. Yogyakarta: Pustaka Pelajar Munslow, A. 1997. Deconstructing History. London: 11 New Fetter Lane 